\title{
Learning to Co-operate: China's Multilateral Approach to Asian Financial Co-operation*
}

Injoo Sohn

\begin{abstract}
This study explains the ideational sources of China's proactive multilateral diplomacy towards Asian financial co-operation by employing a learning thesis. Challenging prominent materialist explanations (power-transition thesis, realist balancing thesis and economic utility thesis), this study argues that the collective learning of Chinese policy elites through cognitive dissonance, feedback effects and transnational persuasion explains much of the change in China's relational identity and philosophical beliefs regarding regional co-operation. These prior ideational shifts helped to determine China's behaviour change from its muted opposition to Asian financial co-operation in the 1990s to its active support of regional financial co-operation in the early 2000s, as evidenced in the emergence of the Chiang Mai Initiative, Chinese-Japanese-South Korean trilateral financial cooperation and the Asian Bond Fund Initiative. Chinese learning also suggests that more fundamental changes in China's national preference may make its support for Asian financial co-operation more consistent and stable in the foreseeable future than sceptics might anticipate.
\end{abstract}

Asian financial co-operation is emerging, and China is an important cause. What has motivated China to support Asian financial co-operation in recent years? Does this policy simply reflect a temporary tactic to change the interstate power configuration in China's favour as many structural realists suggest? Or is it conceivable that more fundamental changes in China's national preference will make its support for Asian financial co-operation more consistent and stable in the foreseeable future than sceptics might anticipate? This article provides an ideational explanation for China's multilateral diplomacy towards Asian financial co-operation. In so doing, it intends to shed light on the general question of whether and how a rising authoritarian power such as China can learn to co-operate in an era of economic globalization (that is, preference change).

The central argument of this study is that the collective learning of Chinese policy elites through cognitive dissonance, feedback (or legitimacy) effects and

* The author is grateful to Bruce Dickson, Mike Mochizuki and Susan Sell for their encouragement and feedback.

(C) The China Quarterly, 2008 doi:10.1017/S0305741008000398 
transnational persuasion explains much of the change in China's relational identity and philosophical beliefs regarding regional co-operation. These prior ideational shifts helped to determine China's behaviour change from its muted opposition to Asian financial co-operation in the 1990s to its active support of regional financial co-operation in the early $2000 \mathrm{~s}^{1}$

More broadly, the findings have significant implications for Asian regionalism and global financial governance. Given that the support of other East Asian countries for regional financial co-operation remained largely constant in the 1990s and early 2000s, China's policy change made an important difference to the way Asian financial co-operation emerged. Without China's embrace of regional multilateralism, Asian financial co-operation could not have come into being in the early 2000s. At the regional level, the rise of new financial cooperative mechanisms would be an important step forward for an Asian regional integration project. $^{2}$ At the global level, the development of Asian regional financial co-operation would help to reduce the dependence of East Asia on International Monetary Fund (IMF) support in crisis management and finance for development, and thereby increase the autonomy and bargaining power of East Asia vis-à-vis the rest of the world, and the United States in particular. This would give Asia an added voice in affecting the shape of new global financial governance in the 21 st century. Despite such important policy implications, China's approach to Asian financial co-operation has been seriously overlooked, especially when compared to other Chinese economic issues such as trade, foreign direct investment and economic reforms, as well as other subfields of Chinese foreign and security policy.

What is new in Chinese policy towards Asian financial co-operation in the early 21st century? First, China has been actively participating in the construction of semi-multilateral regional financial swap arrangements under the Chiang Mai Initiative (CMI) since 2000. The CMI is designed to provide liquidity support for member countries that experience short-term balance-ofpayment deficits in order to prevent an extreme crisis in a country and a subsequent regional contagion. In accordance with the CMI, China signed a series of agreements with Thailand, Japan, South Korea, Indonesia, Malaysia and the Philippines addressing the regional monetary-stability fund. As of March 2005, the total amount committed by China in the signed swap arrangement reached US\$11.5 billion. In May 2005, Beijing even declared that it would "double the scale of its commitment to the CMI" from its current level. ${ }^{3}$

1 My argument about Chinese learning does not necessarily underestimate China's "worship for national interest" in its foreign policy. This study primarily examines how certain components of national interests are conceptualized, rather than whether national interests per se matter.

2 See, for example, Heribert Dieter and Richard Higgott, "Explaining alternative theories of economic regionalism: from trade to finance in Asian co-operation?" Review of International Political Economy, Vol. 10, No. 3 (2003).

3 "China, Japan, South Korea, ASEAN make moves for Asian Monetary Fund," Agence France Presse, 6 May 2005, World News Connection (WNC) online. This is the online successor to the Foreign Broadcast Information Service hardcopy. 
At the same time, China's state-run commercial banks began to form strategic trilateral alliances with their Japanese and South Korean counterparts. For example, the Bank of China signed a co-operative agreement with the Korean Exchange Bank and the Sumitomo Mitsui Bank in August 2003. This trilateral business alliance focuses on e-trade finance, settlement service, investment supports and project financing in the three countries. Likewise, the China Development Bank also agreed to establish the Northeast Asia Development Financing Council with the Korea Development Bank and the Mizuho Bank in May 2004. According to the trilateral agreement, the Financing Council would contribute to co-ordinating development project financing and establishing advanced financial infrastructure in the region. In addition to the trilateral strategic alliance, the Chinese government also allowed the central banks of South Korea and Japan to open regional offices in Beijing in 2003.

Meanwhile, China has also been actively participating in the creation of the Asian Bond Fund (ABF) since 2003. The establishment of the ABF ultimately aims, first, to bring back the huge amount of Asian foreign reserves that were traditionally saved in Europe or in the US to be used in bond investments throughout Asia, and second, to shield the region from external vulnerabilities by building more robust and diversified local capital markets. The member countries of the ABF include Australia, China, Hong Kong, Indonesia, Japan, South Korea, Malaysia, New Zealand, the Philippines, Singapore and Thailand. With its close consultation with the mainland Chinese government, Hong Kong's monetary authority has been in charge of the ABF as the incumbent chairman of the financial market working group of the Executives' Meeting of East Asia and Pacific Central Banks. Hong Kong was also chosen by the meeting's member countries as the preferred centre for the initial listing of the Pan-Asian Bond Index Fund (PAIF). In May 2005, the Chinese government approved the PAIF to trade on the Chinese interbank bond market - bonds issued by Chinese banks.

Why has China come to join and promote Asian financial co-operation in recent years? For example, given China's concern about the influence of Japan in the region, why did it support and implement the Japan-initiated regional financial swap arrangement in 2000 (the CMI) after being sceptical about it for the past decade? This is in contrast to China's muted opposition to the Japanproposed idea of the Asian Monetary Fund (AMF), the Asian version of the IMF, in 1997. This puzzle has an important bearing on a broader phenomenon that has emerged in Chinese foreign policy since the late 1990s: China's increased tendency to engage multilateral institutions and arrangements at the regional level. China has actively engaged new regional multilateral arrangements, such as the ASEAN + 3, China-ASEAN Free Trade Area, Shanghai Co-operation Organization and Asian Community Summit.

This is a striking departure from China's long-standing emphasis on autonomy and independence. In the past, China was concerned that in 
multilateral settings it would be outvoted and its bargaining power decreased. ${ }^{4}$ With respect to regional multilateralism, it suspected that Japan would use regional co-operation to secure raw materials and markets, and enhance its influence in the region. ${ }^{5}$ China therefore took a minimalist and passive approach to Asia-Pacific regional co-operation prior to the late 1990s. Hence its active embrace of recent Asians-only regional co-operation ${ }^{6}$ remains a puzzle that defies the conventional wisdom about Chinese foreign policy. The phenomenon can be best explained by the learning model developed in this study.

In order to measure Chinese learning on Asian regional financial cooperation, this study traces the views of a carefully chosen group of Chinese policy elites during the 1990-2005 period. They include the top officials in the Politburo, the Ministry of Foreign affairs, the Ministry of Foreign Trade and Economic Co-operation, the Ministry of Finance, the People's Bank of China, as well as analysts in the government-controlled media (such as the Xinhua News Agency) and academic institutions (such as the Chinese Academy of Social Science). By closely monitoring the views of these policy elites and by comparing relevant individuals and groups over time, the present study examines evidence of state learning. It attempts to avoid some of the elementary pitfalls of research on learning by specifying the time period and by defining and measuring behaviour and beliefs in non-tautological ways. Nevertheless, one of the key methodological problems is the fact that Chinese leaders' public statements and journal articles may be more like attempts to influence the audience rather than genuine beliefs. This study seeks to reduce such distortions by relying on internally circulated weekly governmental archives, interviews and contemporaneous public statements by officials. Greater credibility is given to internal documents and to unrehearsed and personally expressed views for which there is no clear self-serving political motive. In 2004, I also conducted interviews with more than 40 key Chinese specialists in the field of Chinese security and economic policy, and Korean and Japanese government officials who were engaged in dialogue with their Chinese counterparts to complement the documentary evidence. ${ }^{7}$

It is important to note that this study focuses on the centre point of governmental views, that is, the consensus representing the view of dominant policy elites within the government, rather than the views of particular elites. Although the study does not assume the Chinese state as a unitary actor, its

4 See, for example, Wu Xinbo, "Four contradictions constraining China's foreign policy behavior," Journal of Contemporary China, Vol. 10, No. 27 (2001) and Alastair Iain Johnston, "Beijing's security behavior in the Asia-Pacific: is China a dissatisfied power?" in J.J. Suh, Peter Katzenstein and Allen Carlson (eds.), Rethinking Security in East Asia (Stanford: Stanford University Press, 2004).

5 Yong Deng, Promoting Asia-Pacific Economic Co-operation: Perspectives from East Asia (New York: St Martin's Press, 1997), p.57.

6 While China had been participating in "Asia-Pacific" co-operative arrangements since the mid-1980s (e.g. the Asian Development Bank, Pacific Economic Co-operation Council and the Asia-Pacific Economic Co-operation), its active support of East Asians-only co-operative arrangements (excluding the US) is a new phenomenon that has emerged since the late 1990s.

7 A majority of the Chinese interviewees are affiliated with government-sponsored think tanks in Beijing and Shanghai. They are not key decision-makers but knowledgeable about the Chinese decisionmaking process. 
primary concern is not the specific content of lessons learned by particular individuals, but changes in governmental consensus. ${ }^{8}$ It attempts to capture such governmental consensus over time by looking at internal documents, white papers, the journals of government-sponsored institutes and governmentcontrolled media editorials representing the basic guidelines for Chinese foreign policy.

For reasons of space, I focus on explaining why China's new regional policy emerged on the issues of international finance, rather than describing what it was. The first of the article's three sections briefly examines the explanatory power and limitations of the prominent materialist explanations, and shows how the learning explanation can complement and outperform these explanations. The second section discusses the sources of Chinese learning in the late 1990s with respect to Asian regional co-operation. The last section explains the substance of Chinese learned ideas and its causal relationship with China's foreign financial policy behaviour in the early 2000 s.

\section{Materialist Alternative Explanations and their Limitations}

This section critically reviews prominent alternative hypotheses, such as the power-transition thesis, realist balancing thesis and economic utility thesis. These materialist alternative hypotheses have some explanatory power. To the extent that the alternative explanations dismiss learning dynamics, however, they suffer from theoretical indeterminacy and empirical anomalies.

A first materialist hypothesis is that China's increasing relative material power allows it to gain more self-confidence and thereby participate in regional multilateral mechanisms to shape the rules of international relations in its favour. This explanation falls within a power-transition version of realism. ${ }^{9}$ However, its main problem is that, at least conceptually, there is no clear reason why a rising power (such as China) should participate in many multilateral institutions and arrangements, given the possibility that reigning powers (such as the United States, Japan and Australia) would dominate the rising power in multilateral settings. ${ }^{10}$ In addition, it is also conceptually plausible that the logic of increasing material power can go in two opposite directions. Increasing power might allow state actors not merely to value but also to disvalue multilateral diplomacy (as in the case of the recent US unilateralism under the Bush

8 Although the anecdotal evidence I collected suggests that there is no perceptible division across Chinese bureaucratic agencies over Asian financial co-operation, it is hard to reject completely the bureaucratic hypothesis given the limited documentary evidence available to us. When new information becomes available, we will be able to assess whether the bureaucratic thesis might have the value-added in explaining the puzzle in my case study.

9 For the literature on power-transition realism, for example, see A.F.K. Organski and Jacek Kugler, The War Ledger (Chicago: Chicago University Press, 1980) and Robert Gilpin, War and Change in World Politics (Cambridge: Cambridge University Press, 1981).

10 Alastair Iain Johnston, "Socialization in international institutions: the ASEAN way and international relations theory," in John Ikenberry and Michael Mastanduno (eds), International Relations Theory and the Asia-Pacific (New York: Columbia University Press, 2003). 
administration). The degree of material power alone cannot point to any particular policy direction.

A second competing explanation is the realist balancing thesis. From the realist perspective, external pressures could encourage China to adopt more cooperative postures in regional multilateral arrangements, including financial cooperation. There are at least two strands of the realist balancing thesis. One emphasizes China's intention to balance against the United States and Japan in the region. For example, as Thomas Christensen aptly notes, China's increased fear of American bilateral diplomacy, such as the US-Japan alliance in the region since 1996, led it to view some form of multilateralism as a more effective means to counterbalance these two powers. ${ }^{11}$ Another variant of the realist hypothesis maintains that China's embrace of Asian financial co-operation was driven by its need to reduce "China threat" perceptions in the region by showing its benign behaviour. ${ }^{12}$

However, such realist explanations leave the puzzle of the timing of China's promotion of regional multilateral financial co-operation. If it is simply a balance-of-power (or threat) consideration that determines China's foreign financial policy behaviour, one would expect it to employ financial multilateralism much earlier than it did in the 2000s. But the evidence is somewhat puzzling. China did not support the idea of the AMF - which, incidentally, Japan, South Korea and the ASEAN countries supported - during the 1997-98 Asian financial crisis. The realist view would predict that China's security concerns regarding American bilateral alliances would lead it to endorse the AMF, and thereby improve its relationship with its neighbours. This behaviour of opposing the AMF is also inconsistent with China's expected policy adaptation to show more co-operative behaviour, thus reducing "China threat" perception which had circulated in the region throughout the $1990 \mathrm{~s}$

A final materialist hypothesis stresses the economic utility of regional financial co-operation for China. This argument maintains that China decided to co-operate in order to gain economic benefits. However, there is no obvious sign that economic rationale directed China to seek regional multilateral options which it had been uneasy with in previous decades. First, China had no pressing need for additional liquidity from the region. At the end of 2001, China's central bank, together with Hong Kong's monetary authority, had reserves of over US $\$ 300$ billion, more than enough for an economy that enjoys the additional safety net of comprehensive capital controls. ${ }^{13}$ Moreover, for China, other unilateral,

11 Thomas Christensen, "China, the US-Japan alliance, and the security dilemma in East Asia," International Security, Vol. 23, No. 4 (1999).

12 See, for instance, Avery Goldstein, Rising to the Challenge: China's Grand Strategy and International Security (Stanford: Stanford University Press, 2005), ch. 6.

13 According to an internal document, many Chinese financial analysts believed that even in the midst of the Asian financial crisis, China was not vulnerable to the crisis because of its comprehensive capital controls. See "Dui guoji jinrong fengxian fangfan de ruogan sikao yu jianyi" ("Some thoughts and suggestions about preventing international financial crisis"), Lingdao canyue (Leadership Reference Reading), 15 January 1998. 
bilateral and global options would be sufficient to prevent and manage potential financial crises. It is unclear to what extent any regional financial co-operative mechanism would benefit China in a strict economic sense. Thus it is not evident that China faced an economic imperative of regional multilateralism to tackle potential international financial problems.

Two questions stand out from this review. First, how can we resolve the indeterminacy of the materialist alternative explanations on the question of the timing of Chinese ideational (or discourse) and behavioural (or practice) changes? Second, given that economic and security imperatives do not point to any particular policy option (that is, a regional multilateral option versus unilateral, bilateral or global options), how can we explain the direction of Chinese ideational and behavioural changes?

\section{Learning I: The Source and Process of Ideational Change}

For the purposes of this study, state learning is defined as changes in the centre ground of governmental views as the result of, first, experience or study of past policy and crisis, and second, dialogue with the transnational epistemic community. The primary focus of the study is on changes in articulated Chinese policy elites' identities and beliefs on international affairs in general, and regional economic co-operation in particular. In this study, I divide state learning into two conceptually distinctive processes for analytical purpose: learning I (ideational change) and learning II (behavioural change). Learning I concerns the question of whether and how state learning occurs. This is about the source of ideational changes. Learning II addresses the question of whether and how the learned ideas can affect policy behaviour. This is about the consequence of ideational changes. ${ }^{14}$

What has driven ideational change? We can trace the cognitive source and process of China's learning in the following three interrelated processes: cognitive dissonance, feedback (or legitimacy) effects, and transnational persuasion.

14 One can conceptually distinguish learning from adaptation. Adaptation does not involve any fundamental changes in cognitive structures. According to this view, foreign policy decision-makers simply respond to environmental change by using instrumental rationality. See Alastair Iain Johnston, "Learning versus adaptation: explaining change in Chinese arms control policy in the 1980s and 1990s," The China Journal, No. 35 (1996). His sophisticated dynamic model marked a departure from the existing perception-matter-research tradition in Chinese studies, which tended to sidestep questions about the dynamic process of ideational changes. While this excellent work served as a reference point for the more recent studies of Chinese foreign policy, further refinement is possible. First, the dichotomy between adaptation and learning may be overdrawn. In practice, initial adaptation to environment may lead to new world-views and constitute (incremental) learning. This view was shared by many contributors to David M. Lampton (ed.), The Making of Chinese Foreign and Security Policy in the Era of Reform (Stanford: Stanford University Press, 2001). Secondly, it is difficult to measure environmental changes, a concept that "adaptation" highlights. The term "environmental change" is often too fluid and diverse for rigorous empirical testing. Even when it is narrowly defined, for instance, as a shift in material distribution of power in the international arena, its real causal effect on behaviour often depends on the actor's interpretation of it. Thus the line between structural and cognitive variables becomes more blurred than the adaptation thesis supposes. 


\section{Cognitive dissonance}

This type of cognitive process can take place at the individual level. Actors can confront negative consequences that might contradict their expectations, hence generating pressures for an existing belief to be changed. In this case, actors can engage in a high intensity process of cognition and reflection about the new information.

Fan Gang (樊纲), a renowned Chinese economist and member of the Monetary Policy Committee of the People's Bank of China, noted that the fever of China's discussion and study of the Asian financial crisis in 1997-98 was unprecedented. Fan said that "there had been very few international affairs which resulted in widespread debates (guangfan yantao 广泛研讨), enthusiastic study (renzhen yanjiu 认真研究) and profound lessons (shenke jiaoxun 深刻教训) like the Asian financial crisis." ${ }^{\prime 15}$ In his view, this was not least because there were similar economic problems, geographical proximity and cultural affinity between the crisis-hit countries and China. ${ }^{16}$ Many Chinese policy elites confronted psychological dissonance as the Asian financial crisis provided deviant information which was inconsistent or directly contradictory to Chinese prior beliefs in the "Asian development model." ${ }^{, 17}$ Up to this time, most Chinese policy elites believed that the developing experiences of East Asian countries offered an effective and reliable way of catch-up modernization. The crisis raised questions about Beijing's faith in the Asian development model and the bright future of the Asian regional economy. ${ }^{18}$ Moreover, the political transition in Indonesia following the crisis stunned and worried Chinese Communist Party (CCP) leaders. During Indonesia's financial crisis, rapidly rising economic hardship and dislocation generated mounting protests, violence and disaffection among the elites. As a result, in late May 1998, abandoned by almost all his supporters, the Indonesian autocrat Suharto stepped down amid of a sea of violence and destruction. To many Chinese leaders and policy elites who had been concerned about political stability and CCP regime survival, this event portrayed the importance of financial and economic security to political security or even regime survival. ${ }^{19}$ Hence, new information and knowledge about

15 Fan Gang, "Dongya jinrong weiji dui woguo de jiaoxun" ("Our country's lessons about the Asian financial crisis"), Zhuanlue yu guanli (Strategy and Management), No. 2 (1998), p. 61.

16 Some works by psychologists suggest that vivid information has a disproportionately strong impact on people's ideas. Information is likely to hold our attention and be remembered if it is emotionally interesting and proximate in a temporal or spatial way. See Richard Nisbett and Lee Ross, Human Interference: Strategies and Shortcomings of Social Judgment (Englewood Cliffs, NJ: Prentice-Hall, 1980), p. 44 and Dan Rieter, Crucible of Beliefs: Learning, Alliances, and World Wars (Ithaca, NY: Cornell University Press, 1996), pp. 27-28.

17 Author's interview, Shanghai, March 2004.

18 It should be noted that the result of the Chinese study of the Asian financial crisis was by no means the complete devaluation of the Asian development model. While Chinese analysts found certain aspects of the Asian development model problematic in application, they tended to emphasize the problems of extant international economic order and governance as a source of the Asian financial crisis. Nevertheless, the crisis contributed to allowing Chinese policy elites to engage in an intensive process of cognition and reflection about the new information: "cognitive dissonance."

19 Author's interview, Beijing, May 2004. 
financial management and economic security was increasingly viewed by Chinese policy elites as desirable for their national interest.

Beijing's cognitive dissonance with the help of vivid information and the desirability of new ideas (two favourable ideational conditions) triggered a nationwide wave of intensive debates and studies of the Asian financial crisis and global (and regional) political economy among Chinese officials and intellectuals. For example, China's State Council held an unusual high-level National Finance Work Conference in Beijing on 17 November 1997 to discuss the problems of China's financial and banking system. Participants in the meeting included not only officials from the central bank at the national and provincial levels, China's state-owned banks, and many non-bank financial institutions, but also all provincial governors and provincial-level finance officials and several members of the Standing Committee of the CCP Politburo. Likewise, the CCP Central Committee convened a special session on financial security on 12 May 1998. The CCP Central Committee even organized a training course on finance for senior Party and government officials from provinces, autonomous regions, military area commands and central departments in January 1999. This domestic learning could set the stage for the emergence of new governmental ideas, such as a "pan-Asian identity" and a "positive-sum view" (discussed in the next section).

\section{Feedback (or legitimacy) effects}

Feedback effects can occur on the organizational level. When the policy proposed by actors receives a positive feedback, their political legitimacy and influence may increase within the government. Accordingly, their ideas are more likely to contribute to state learning. Conversely, when actors' policy ideas are seen as responsible for failed policies, they will lose their political legitimacy and influence, and their ideas became less salient within the government. ${ }^{20}$ In this respect, organizational learning is a political as well as a cognitive process. Ideas can help determine the balance of power among competing factions within the government.

China's positive evaluation of earlier multilateral diplomacy allowed it to feel more confident and comfortable with the idea of regional multilateral financial co-operation. As Tang Shiping (唐世平), ${ }^{21}$ a prominent foreign policy analyst at the Chinese Academy of Social Sciences put it, China's participation in regional multilateralism created "a self-reinforcing virtuous cycle propelling China's regional strategy." According to Tang, "positive policy outcomes from the ASEAN Regional Forum (ARF), 10+1/10+3, and the Shanghai Co-operation Organization have all strengthened the voice of integrationist or institutionalists,

20 Robert Jervis, Perception and Misperception in International Politics (Princeton:Princeton University Press, 1976), p. 238.

21 Shiping Tang, "China's regional strategy: an interpretation," Center for Regional Security Studies Working Paper (Beijing: Chinese Academy of Social Sciences, 2004), p. 18. 
leading to call for more active participation in regional multilateral initiatives." Likewise, recent scholarly works ${ }^{22}$ point to a considerable change in China's attitude towards regional multilateral security co-operation, from outright rejection or suspicion in the early 1990s to active support in the late 1990s through China's experience of the ARF. According to some Chinese interviewees in a Shanghai-based policy community, ${ }^{23}$ those who initially promoted the idea of proto-multilateralism gained more credit and attention from the top leadership who became increasingly convinced that this would serve China's national interest. The new ideas of multilateralism were increasingly seen by the Chinese leadership as desirable for the national interest. As the proto-multilateral activists were perceived to be responsible for policy success, they could exert even more political influence within Chinese policy circles and have been continuously encouraged to offer creative policy ideas to the leaders since the late 1990s. This indicates certain types of feedback effects at the Chinese organizational level. Such feedback effects contributed to increasing the level of confidence in regional multilateralism (including Asian financial cooperation) with which China had been uneasy in the past decades.

\section{Transnational persuasion}

On the international level, ideational change can take place through international contact and persuasion. Persuasion involves the non-coercive communication of ideas. Transnational persuasion can lead to common knowledge or homogenization of interests. Thus it can reduce the gap between actors' ideas. In the case of Asian financial co-operation, from the late 1990s, China's neighbouring countries had facilitated its learning by attempting to persuade it of the common benefits of regional co-operation, and providing knowledge and lessons. Given China's inexperience of international financial management, the availability of these new ideas from outside could facilitate the diffusion of new ideas to Chinese policy elites.

The Asia-Europe Meeting (ASEM) and the ASEAN+3 helped to transmit new ideas of Asian financial co-operation in the late 1990s. These two multilateral frameworks provided a useful avenue for discussing Asian financial co-operation more frequently. For example, Asian countries discussed the Japanese-proposed idea of a new Asian currency regime composed of a basket of currencies in ASEM's London meeting in 1998. Similarly, the ASEAN+3 first met to discuss the establishment of a permanent regional fund in January 1999. The increased frequency of interactions among Asian countries over common concerns and interests could provide better information about the benign nature

22 See, for instance, Rosemary Foot, "China in the ASEAN Regional Forum," Asian Survey, Vol. 38, No. 5 (1998) and Alastair Iain Johnston, "Beijing's security behavior in the Asia-Pacific: is China a dissatisfied power?” in J.J. Suh, Peter Katzenstein and Allen Carlson (eds.), Rethinking Security in East Asia (Stanford: Stanford University Press, 2004).

23 Author's interview, Shanghai, April 2004. 
of co-operation, thus reducing China's suspicions of it. ${ }^{24}$ This is in contrast to the case where Japan proposed the AMF without consulting China in 1997.

Another effect of the ASEAN+3 and the ASEM process is that transnational dialogues helped to develop a pan-Asian identity among Asian countries, including China. The ASEAN+3 (Asians-only grouping) contributed to an increased sense of group differentiation between East Asia and others, resulting in solidarity among East Asian members. Interestingly, the ASEM also helped to consolidate a pan-Asian identity. As each ASEM discussion requires Asia to take a co-ordinated position vis-à-vis the relatively uniform EU, Asia had more incentive to create a collective Asian identity within the framework. ${ }^{25}$ In short, the increased frequency of China's interactions and dialogues with its neighbours in the post-Asian financial crisis period also laid a solid foundation for the emergence of China's new identity and philosophical beliefs about international affairs.

\section{Learning II: Causal Relationship between Learned Ideas and Policy Behaviour}

As the next step of the learning process, this section discusses causal pathways between learned ideas and policy behaviour. For analytical purposes, the present study focuses on two distinctive ideational dimensions: relational identity (ingroup/out-group differentiation) and philosophical beliefs (world views). Such notions here are used to denote more fundamental ideational shifts which go beyond changes in instrumental beliefs (means/ends calculation).

\section{Relational identity}

The key causal process in behaviour is in-group/out-group differentiation. In social identity theory, ${ }^{26}$ self-categorization tends to produce competitive behaviour with out-groups, as it leads to a positive evaluation of in-groups and a negative assessment of out-groups. Meanwhile, a growing in-group identity increases solidarity and thereby co-operation among members of a group. For instance, a relational identity could help a country to interpret and internalize the new information provided by its in-group countries. The same

24 China and other East Asian countries shared their discontent with the post-Asian crisis global financial architecture. They were particularly unhappy with the under-representation of Asia in the G7-centred decision-making structure of global financial governance. This problem facilitated the Asian pursuit of regionally differentiated solution over global ones. For a detailed discussion of this issue, see Injoo Sohn, "Asian financial co-operation: the problem of legitimacy in global financial governance," Global Governance, Vol. 11, No. 4 (2005).

25 Saori N. Katada, “Japan's counterweight strategy: US-Japan co-operation and competition in international finance," in Ellis S. Krauss and T.J. Pempel (eds.), Beyond Bilateralism: US-Japan Relations in the New Asia-Pacific (Stanford: Stanford University Press, 2004), p. 195.

26 See, for example, Marilynn B. Brewer and Wendi Gardner, "Who is this 'we'?: levels of collective identity and self-representations," Journal of Personality and Social Psychology, Vol. 71, No. 1 (1996) and Richard Ashmore and Lee Jussim, Self and Identity: Fundamental Issues (New York: Oxford University Press, 1997). 
information can be interpreted differently depending on whether it came from like-minded people or devalued others: information from friends is more persuasive than that from strangers. ${ }^{27}$

In Chinese policy discourse in the early 1990s, many Chinese analysts largely used the terms "Asia Pacific" grouping (including the United States and the (former) Soviet Union) or "West Pacific socialist" grouping (including China, the Soviet Union, North Korea, Mongolia, Laos and Vietnam). ${ }^{28}$ In the first half of the 1990s, there were very few accounts of an Asians-only grouping in Chinese discourse. But in the late 1990s the differentiation of East Asia versus others became more salient. China's experience with the Asian financial crisis contributed to an increasing sense of a pan-Asian identity within the Chinese leadership, and its discontent with the IMF-prescribed solutions to the crisis reinforced its resentment against perceived Western arrogance and triumphalism. In East Asia, including China, there was a strong sense that the West in general, and the United States in particular, used the Asian financial crisis to advance a particular economic agenda aimed to serve selfish interests. ${ }^{29}$ In Beijing's view, the IMF approach dismissed the importance of the noninterference and independence principle shared by almost all regional states that had bitter experiences with (semi) colonial rule, big-power intervention and treaty orchestration by the major powers during the Cold War. ${ }^{30}$ The resentment caused by post-crisis IMF reforms led China to share with its Asian neighbours the sense of common (potential) victim vis-à-vis the Western "gang." "31 This breathed new life into the relational identity of Asia versus others in China.

Moreover, as noted in the previous section, new regional forums such as the ASEAN+3 and the ASEM also helped to increase the incentive for China to develop its regional identity. China's pan-Asian identity provides an important social context for China and its neighbouring Asian countries to increase solidarity among East Asian countries, as evidenced in the creation of East Asians-only financial co-operative arrangements. In November 2000, the then

27 James H. Kuklinski and Norman L. Hurley, "It's a matter of interpretation," in Diana C. Mutz, Paul M. Sniderman and Richard A. Brody (eds.), Political Persuasion and Attitude Change (Ann Arbor: University of Michigan Press, 1996).

28 See, for example, Qin Yongchun, "Shilun Sulian Dongzhou de bianhua yu yatai diqu xingeju" ("A discussion of the transformation of the Soviet Union and Eastern Europe, and the new configuration of Asia-Pacific region"), Shijie jingji yu zhengzhi (World Economics and Politics), No. 11 (1990); Yan Yang and Chu Dao, "Yatai diqu anquan wenti ji gefang jiben taidu" ("The problems of Asia-Pacific security and basic attitude"), Xiandai guoji guanxi (Contemporary International Relations), No.7 (1994), and Chen Jiru, "Jiushi niandai shijie jingji diqu yitihua de tiaozhan yu Zhongguo de duice" ("The challenge of the regional economic integration in the 1990s and China's policy response"), Shijie jingji yu zhengzhi (World Economics and Politics), No. 4 (1990).

29 See, for instance, "US using Japan bashing to undermine 'Asian mentality': economic crisis chance to push market principles," Nikkei Weekly, 22 June 1998, WNC online.

30 Author's interview, Beijing, June 2004.

31 For example, a Chinese internal document claimed that while the 1994 Mexico Peso crisis and 1997 Asian financial crisis primarily resulted from global over-production and volatile international capital mobility, the victims of the crises were nation-states in the periphery, rather than the core of the world economy. See "Jingji quanqiuhua dui fazhanzhong Guojia Yiweizhe shenme?" ("What are the implications of economic globalization for developing countries?"), Neibu canyue (Internal Reference Reading), 27 January 1999. 
Chinese Premier Zhu Rongji (朱镕基) articulated China's policy preference for becoming a rule maker (as a member of East Asians grouping) in global financial governance, and called for the earnest implementation of the Chiang Mai Initiative. Zhu claimed that China stood "ready to work with other East Asian countries for the reform of the current international financial architecture" and open to "all ideas" about financial co-operation in the region. ${ }^{32}$ Likewise, in April 2002, Dai Xianglong (戴相龙), the then Governor of the People's Bank of China, made a speech to highlight the shared identity of Asian countries and the need for a collective action of Asian multilateral financial co-operation. Dai said that the "Asian financial crisis has taught us the lesson that if Asian economies could not work more vigorously to set up a mechanism for regional monetary co-operation, it would be difficult to avoid speculative attacks.",33

China had completed the first round of the CMI agreements with Japan, South Korea, Indonesia, Malaysia and Thailand by May 2004. ${ }^{34}$ In April 2004, ASEAN+3 agreed to undertake a further review of the CMI to explore ways in which it could be expanded and consolidated. China chaired a working group to conduct and report the review of the CMI to the ASEAN+3 finance ministers' meeting in May 2005. Accordingly, in May 2005, China and other member countries agreed to double the scale of their total commitments to the CMI from US $\$ 36.5$ billion to around US $\$ 80$ billion. Since late 2005 , China has been negotiating and concluding the second round of the CMI with its Asian counterparts.

\section{Philosophical belief}

Another important causal process between ideas and behaviour is related to actors' ontology and epistemology: how the world works. Philosophical beliefs allow actors to interpret the external world, and affect the valuation of the material or social incentives for particular action. Put differently, philosophical belief refers to something deeper going on behind the scenes of actors' instrumental calculations (or means/ends calculation).

Moderate positive-sum views were increasingly becoming the dominant Chinese view on international affairs from the late $1990 \mathrm{~s} .{ }^{35}$ China's cognitive

32 The Malaysian National News Agency, 25 November 2000, WNC online.

33 Dai Xiangrong, "China's financial opening-up and financial co-operation in Asia," The People's Bank of China-Speeches, 15 April 2002, available at http://www.pbc.gov.cn/english//detail.asp?col=6500\& $\mathrm{ID}=6$.

34 Economic realities in the region mean that potential swap providers are only those with substantial foreign exchange reserves: China, Japan and South Korea. China (potential donor) concluded a set of one-way swap arrangements with ASEAN member countries (potential recipients). China is thus not expected to request liquidity assistance from the ASEAN countries. Chinese policy elites are keenly aware of potential costs or problems arising from the failure of repayment by swap requesting members. Author's interview, Beijing, June 2004.

35 This moderate view emphasizes a positive-sum form of win-win competition in which countries cooperatively pursue security and economic interests, rather than a zero-sum form of competition in which countries struggle to maximize relative power. 
dissonance following the Asian financial crisis helped it to appreciate the downside of economic globalization. That is the problem of "economic security." ${ }^{36}$ China realized that globalization is a double-edged sword (shuangdao jian 双刀剪), possibly leading to a destabilized economy and aggravating the North (developed countries)-South (developing countries) divide unless it is properly managed. Chinese leaders began to hold the view that maintaining economic (and financial) security in an era of globalization is crucial for political stability and CCP regime survival. Then President Jiang Zemin (江泽民) emphasized that to safeguard state economic security, China must first safeguard the security of finance because the normal operation of the financial system is extremely significant to the whole economy. ${ }^{37} \mathrm{An}$ increasing number of Chinese leaders also seemed to believe that there would be growing space for potential co-operation to deal with the common problems of economic security such as international financial contagion. In October 1998, for example, Dai Xianglong (戴相龙), the then Governor of the People's Bank of China, mentioned that rapid economic globalization and the resulting Asian financial crisis led the international community to share concerns about economic security, and realized the need of state participation to strengthen the architecture of international financial governance. ${ }^{38}$

This attitude contrasts with China's primary focus on "relative gains" and "asymmetric interdependence" in the early 1990s. For instance, some leading Chinese analysts believed that the North (beifang guojia 北方国家) could have more gains and less dependence than the South (nanfang guojia 南方国家). From this perspective, China as a developing country (in the South) should be cautious about its entry into regional economic co-operative mechanisms such as an East Asian Economic Caucus. ${ }^{39}$ This view was also supported in part by a Chinese internal document which evaluated the costs and benefits of Mexico's entry into the North American Free Trade Agreement. According to this analysis, the participation of Mexico (a developing country) in the Agreement produced negative effects in the sense that it undermined less competitive domestic industry and increased Mexico's asymmetric interdependence vis-à-vis the United States and Canada (two advanced economies). ${ }^{40}$ In the Chinese discourse of the late 1990s, however, the term "positive sum" (as opposed to the term "zero sum") became more salient, providing additional favourable conditions for China's active embrace of regional financial co-operation.

36 See, for example, "Zengzhang yu anquan: woguo zhongchangqi jingji zhanlue liangda zhuti" ("Growth and security: two big issues in our country's mid and long-term economic strategy"), Neibu canyue, 24 February 1999 and "Yingxiang woguo jinrong anquan de yinsuo ji yingdui cuoshe" ("The factors affecting our financial security and our responding measures"), Neibu canyue, 24 March 1999.

37 "China: editorial on economic efforts in region," Ta kung pao, 18 May 1998, WNC online.

38 "China: China urges strengthening architecture of monetary system Beijing," Xinhua, 7 October 1998, WNC online.

39 See, for instance, Gu Yuanyang, "Woguo miandui nanbei jingji quyuhua qushi de yinying duice" ("Our response to the trend toward South-North regional economic blocs"), Shijie jingji yu zhengzhi (World Economics and Politics), No. 3 (1993), p. 2.

40 "Moxike jiaru beimei ziyou maoyi qu liangnian hou de de yu shi ji dui women de qishi" ("Mexico's gain and loss two years after its entry into NAFTA and its implication for us"), Lingdao canyue (Leadership Reference Reading), No. 31 (1996). 
On a related point, there is China's growing awareness of the "security dilemma" in the late 1990s. The security dilemma theory supposes that mutual suspicion between two or more adversaries can cause each side to take defensively motivated measures that are seen by others as an offensive threat. This can provoke a vicious spiral of tension and counter-measurement. In China's case, little was written about notions such as "security dilemma" and "positive sum" in the first half of $1990 \mathrm{~s} .{ }^{41}$ More specifically, prior to the late 1990s, many Chinese analysts believed that the China threat theory originated from the vicious intentions of other countries, rather than its interaction with others in the world. In 1993, for instance, a Chinese analyst argued that the United States intended to use the China threat theory as a tactic to deflect the attention of the international community away from American intervention in Asian affairs such as arms sale to Taiwan. ${ }^{42}$ In 1996, a renowned Chinese strategist, Yan Xuetong (阎学通) also omitted security dilemma dynamics from his discussion of the origin of the China threat theory. ${ }^{43}$ But since late 1997, Chinese officials and analysts have developed and publicized what is called the “new security concept." For example, China's Foreign Minister Qian Qichen (钱 其琛) made remarks on the subject at the private sector's salute to ASEAN's 30th anniversary in December 1997. According to the Chinese official interpretation, ${ }^{44}$ this concept is characterized by notions such as "common security," "co-operative security" and "comprehensive security." With globalization, countries are "more interdependent on one another for security," and no country can achieve its security without co-operation. As Zhang Yunling (张 蕴岭), president of the China Association for Asia-Pacific Studies and a member of the Chinese People's Political Consultative Conference noted, the new security concept clearly recognized that China's behaviour could cause other states to be concerned about its rising power. ${ }^{45}$ Alastair Iain Johnston's case study also shows that some Chinese policy elites were becoming believers in security dilemma dynamics and the utility of regional multilateralism to deal with the security dilemma. ${ }^{46}$ Such growing positive-sum views and increased awareness of the security dilemma helped China to recognize the value of regional multilateralism. More specifically, these new philosophical beliefs

41 This finding is based upon my review of three prominent Chinese-language journals published by the Chinese government-sponsored institutes during 1990-95: Shijie jingji yu zhengzhi (World Economics and Politics) (the Chinese Academy of Social Sciences), Xiandai guoji guanxi (Contemporary International Relations) (Chinese Ministry of Foreign Affairs' China Institute of Contemporary International Relations), and Lingdao canyue (Leadership Reference Reading) (internally-circulated documents).

42 Wu Peng, "Zhonguo weixie lun buxi" ("An analysis of the China threat theory"), Shijie jingji yu zhengzhi (World Economics and Politics), No. 10 (1993), p. 5.

43 Yan Xuetong, "Xifangren kan Zhongguo de jueqi" ("Western people eye the rise of China"), Xiandai guoji guanxi (Contemporary International Relations), No. 9 (1996), pp. 36-45.

44 "China's position paper on the new security concept," Ministry of Foreign Affairs of the People's Republic of China, 2002, available at http://un.fmprc.gov.cn/eng/33462.html, accessed on 27 March 2005.

45 Zhang Yunling, "Zonghe anquan guan ji dui woguo anquan de sikao" ("The comprehensive security concept and reflection on our country's security") Dangdai yatai, January 2000.

46 Johnston, "Socialization in international institutions." 
encouraged China to take more active approaches to Asian financial cooperation in the early 2000s.

Despite political tensions between Japan and its north-east Asian neighbours over historical issues and disputed islets, the three economic powerhouses of the region - China, Japan and South Korea - have managed to keep intergovernmental financial co-operation on track in the first half of the 2000s. This reflects the resilience of Beijing's new thinking on regional multilateral co-operation. In 2003, the central banks of South Korea and Japan opened offices in Beijing. At the end of 2002, China and other ASEAN+3 countries agreed to organize six working groups to conduct detailed studies on various aspects of the Asian Bond Fund. China chaired a working group to analyse the issuance of bonds denominated in local currency by multilateral development banks, government agencies and Asian multilateral corporations. A team of Chinese financial experts led by Li Yang (李扬), director general of the Finance Research Centre of the Chinese Academy of Social Sciences, led a one-week investigative study with Hong Kong counterparts on the issue of the ABF in August 2003.

Prior to China's official endorsement of the ABF in June 2003, some Chinese analysts were concerned about Japan's influence in the regional bond market. Nevertheless, this did not impede China's growing proactive diplomacy towards regional financial co-operation. Zhong Wei (钟伟), director of Beijing Normal University's International Finance Research Center and a senior government consultant on Chinese foreign financial policy claimed that "if China actively supports the move for an Asian bond market, the Japanese yen will dominate the proposed market and assets valued in yen will become the biggest gainers. China cannot get big direct benefits." However, he added, "the proposal to set up such a common market is highly valuable, and it needs the continuous efforts and close co-ordination of all participants." ${ }^{47}$ Similarly, He Fan (何帆), a research fellow at the Chinese Academy of Social Sciences, said that "even if Japan eats the biggest portion of the cake, China should take part as the country itself can obtain benefits." 48

These remarks demonstrate that an absolute-gain consideration (or positivesum view) took precedence over a relative-gain consideration (or zero-sum view) within the Chinese foreign financial policy community regarding Asian financial co-operation. Beijing's rationale for its promotion of the $\mathrm{ABF}$, as summarized by leading Chinese policy elites in their internal government report, is worth quoting at length:

Even if substantial progress happens to be made in the ABF in the near future, our country [China]'s economic benefit would be very limited ... The ABF has more political, indirect, and long-term than economic, direct, and short-term importance ... China's active participation and leadership in the development of the ABF would not merely improve China's international environment and peaceful development, but also help to

47 "China faces difficult choice over proposed Asian bond market," China Daily, 18 March 2003, available at http://www.mfa.go.th/web/1247.php?id $=4408$. 
reinforce China's image of a responsible great power and thereby facilitate China's integration with Asia and the world, and further comprehensive regional co-operation. ${ }^{49}$

This internal policy discourse features China's new security concept (that is, common, co-operative and comprehensive security) as a significant element of China's new philosophical beliefs. These provided an important rationale for China's embrace of regional financial co-operation in the early 2000s. In accordance with the internal policy recommendation, China, one of the largest contributors, strongly embraced the ABF. With close consultation and support from the mainland Chinese government, Hong Kong's monetary authority has been in charge of the ABF. The People's Bank of China chose China Asset Management Co. as the manager of the China sub-fund of the ABF2 in May 2005. It also approved the Pan-Asian Bond Index Fund to trade on the Chinese interbank bond market, bonds issued by Chinese banks. This is a significant Chinese-initiated measure in international financial policy not least because opening its local bond market was not one of China's commitments to the World Trade Organization.

\section{Conclusion}

The evidence elaborated above demonstrates that China's new governmental ideas about regional multilateralism in general and Asian financial co-operation in particular emerged as a result of cognitive dissonance, feedback effects and transnational persuasion. This state learning produced significant changes in China's relational identity and philosophical beliefs in the late 1990s (learning I) and the prior ideational changes affected Chinese policy behaviour in Asian financial co-operation in the early 21 st century (learning II). China not only enthusiastically participated in the creation and implementation of the de facto regional monetary stability fund under the Chiang Mai Initiative, but also actively supported a series of Chinese-Japanese-South Korean financial cooperative arrangements and the Asian Bond Fund Initiative.

Many structural arguments tend to emphasize that what is important is the degree of China's interdependence, not how China became interdependent. In other words, "interdependence is a predicament countries must deal with, not a world-view or a foreign policy strategy." ${ }^{50}$ Yet this study raises a question about such a deterministic view of global interdependence logic in China's case. Despite its increasingly interdependent context, China's exit costs are relatively low. It can continue to benefit from its global multilateral economic arrangements (such as the WTO and the IMF) and an array of bilateral arrangements, without its commitment to the regional arrangement. China thus

49 "Woguo ying jiji canyu bing zhudao yazhou zhaiquan shichang de fazhan" ("Our country should actively participate in and lead the Asian Bond Market"), Lingdao canyue (Leadership Reference Reading), 15 September 2004.

50 David. M. Lampton (ed.), The Making of Chinese Foreign and Security Policy in the Era of Reform, 1978-2000 (Stanford: Stanford University Press, 2001), p. 36. 
retains substantial flexibility to extract itself from Asian regional co-operation should the need arise. If the exit costs are low, then the issue of Chinese national preference is more significant for the future trajectory of Asian regional cooperation than sceptics initially believed. The learning explanation focuses directly on the nature and scope of changes in Chinese national preference.

My findings of Chinese learning suggest that despite a set of potential political and economic constraints confronting Asian regional co-operation, ${ }^{51}$ China's proactive support for such co-operation will be more consistent and stable in the future than sceptics might think. This is not to say that China's attempted financial co-operation will necessarily lead to successful financial co-operation in the region. The direction of policy change should not be confused with its actual results, not least because the final outcome can be greatly influenced by many international and domestic factors as well as historical contingency. Nevertheless, China's learning and subsequently new national preference is more likely to continue to encourage it to play a leading role in creating and consolidating the new Asian financial arrangements in the foreseeable future. To extend this logic, one may even cautiously anticipate that China's new national preference will help to maintain the momentum of its proactive multilateral diplomacy towards other dimensions of regional co-operation, such as the China-ASEAN Free Trade Area, Boao Forum, Shanghai Co-operation Organization, Six-Party Talks and Asian Community Summit.

51 On this point, see, for instance, Natasha Hamilton-Hart, "Asia's new regionalism: government capacity and co-operation in the Western Pacific," Review of International Political Economy, Vol. 10, No. 2 (2003). 